\title{
THE OXFORD HANDBOOK OF
}

COMPARATIVE

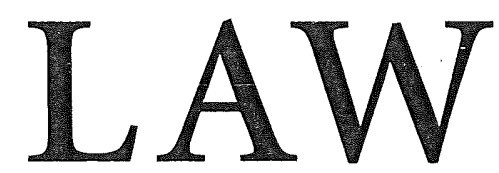

Edited by

MATHIAS REIMANN

AND

REINHARD ZIMMERMANN 


$$
\text { . }
$$




\section{Contents}

Notes on the Contributors

xiii

Abbreviations

xvii

\section{INTRODUCTION}

Comparative Law before the Code Napoléon

Charles Donahue

\section{PART I THE DEVELOPMENT OF COMPARATIVE LAW IN THE WORLD}

1. Development of Comparative Law in France

Bénédicte Fauvarque-Cosson

2. Development of Comparative Law in Germany, Switzerland, and Austria

INGEBORG SCHWENZER

3. Development of Comparative Law in Italy

Elisabetta Grande

4. Development of Comparative Law in Great Britain John W. CaIrns

5. Development of Comparative Law in the United States David S. Clark

6. Development of Comparative Law in Central and Eastern Europe 
7. Development of Comparative Law in East Asia

Zentaro Kitagawa

8. Development of Comparative Law in Latin America

261

JAN KLEINHEISTERKAMP

\section{PART II APPROACHES TO COMPARATIVE LAW}

9. Comparative Law and Comparative Knowledge 305 Nils JANSEN

10. The Functional Method of Comparative Law

Ralf Michaels

11. Comparative Law: Study of Similarities or Differences? 383 Gerhard DanNEMANN

12. Comparative Legal Families and Comparative Legal Traditions H. Patrick GlenN

13. Comparative Law as the Study of Transplants and Receptions 441 Michele Graziadei

14. Comparative Law and the Study of Mixed Legal Systems JACQues du Plessis

15. Comparative Law and its Influence on National Legal Systems JAN M. SMITS

16. Comparative Law and the Europeanization of Private Law REINHARD ZIMMERMANN

17. Globalization and Comparative Law 579 Horatia Muir Watt

18. Comparative Law and the Islamic (Middle Eastern)

Legal Culture 609 
19. Comparative Law and African Customary Law

T. W. BENNETT

20. Comparative Law and Language

675

Vivian Grosswald CURran

21. Comparative Law and Legal Culture

709

Roger CotTERRELL

22. Comparative Law and Religion

HAROLD J. BERMAN

23. Comparative Law and Legal History

JAMES GORDLEY

24. Comparative Law and Socio-legal Studies

775

Annelise Riles

25. Comparative Law and Critical Legal Studies

Ugo Mattei

26. Comparative Law and Economic Analysis of Law

FLORIAN FAUST

\section{PART III SUBJECT AREAS}

27. Sources of Law and Legal Method in Comparative Law

Stefan Vogenauer

28. Comparative Contract Law

E. Allan Farnsworth

29. Comparative Sales Law

Peter Huber

30. Unjustified Enrichment in Comparative Perspective

DANIEL VISSER

31. Comparative Tort Law

1003

Gerhard WAgNeR 
32. Comparative Property Law

SJEF VAN ERP

33. Comparative Succession Law

Marius J. De WaAL

34. Comparative Family Law

1099

HarRy D. KRAUSE

35. Comparative Labour Law

Matthew W. Finkin

36. Comparative Company Law

Klaus J. Hopt

37. Comparative Antitrust Law

David J. GERBER

38. Comparative Constitutional Law

Mark Tushnet

39. Comparative Administrative Law

JOHN S. BELL

40. Comparative Criminal Law

Markus Dirk DubBer

41. Comparative Civil Procedure

JOACHIM ZeKOLL

42. Comparative Law and Private International Law

Mathias Reimann

Index 


\section{DEVELOPMENT OF COMPARATIVE LAW IN GERMANY, SWITZERLAND, AND AUSTRIA}

INGEBORG SCHWENZER

Basel $^{*}$

I. Introduction 70

II. The Long Nineteenth Century. 71

1. Philosophical and Political Traditions . 71

2. The Evolutionary Paradigm 73

3. Legislative Comparative Law 74

4. Early Stages of Institutionalization $\quad 75$

III. A Golden Age (1919-1933) 77

1. The Weimar Republic and the Pre-eminent Influence of Ernst Rabel

2. The Kaiser-Wilhelm Institutes 79

3. Sale of Goods $\because \quad 80$

* This article could not have been written without the collaboration of the historian lic. phil. Simone Peter. It is only for editorial reasons that she is not mentioned as a co-author. All translations from German texts, unless otherwise indicated, are by the author. 
IV. Rupture and Remorse (1933-1950) 82

1. The Policy of Gleichschaltung 82

2. National Socialist Comparative Law? $\quad 84$

3. Continuity 87

V. Recovery (1950-1989) 88

1. General Aspects and Institutionalization 88

2. Methods and Fields of Interest 90

(a) Methodological Foundationș $\quad . \quad 90$

(b) Fields of Interest 91

3. Comparative Law Scholarship in the Post-War Era: Some
(a) Comparative Law in General
(b) Law of Sales
(c) Tort Law
(d) Law of Restitution $\quad 95$
(e) Family Law and the Law of Succession . 96
(f) Conflict of Laws $\quad 96$
4. Comparative Law in Legislation and Courts 97

VI. Legal Harmonization and New Approaches to Comparative Law $\quad \therefore \quad 99$

1. Development of the German Bürgerliches Gesetzbuch 99

2. The Interpretation of Uniform Law 100

3. Europeanization 100

(a) The Classical Comparative Approach 101

(b) The Ius Commune Approach . . . 102

(c) Practical Endeavours 103

4. Criticism 103

VII. Conclusion 104

\section{INTRODUCTION}

THIs chapter attempts to give an overview both of the development of comparative law as a field of research, and of its impact on legal changes in Germany, Switzerland, and Austria. General aspects of the methodology, institutionalization, and the use of comparative approaches by courts and legislators in each of those three countries are therefore considered, with a primary focus on the development of comparative law in the field of the law of obligations.

Any attempt at periodization is to some extent arbitrary, for it suggests a division of historical time, which is, as such, continuous. Historians generally mistrust dividing history into periods following the so-called 'political' or 'diplomatic' 
framework narrative. In fact, it is questionable whether political events have importance for any fields other than politics. Furthermore, cultural and social developments do not follow a precise decimal chronology. Nevertheless, the use of historical periods of time can be helpful. Also, in this particular case, there appear to be convincing reasons for relying upon the political framework to produce a history of comparative law. Moreover, this history, especially in Germany, is linked very closely to the large-scale events of European history.

Section II of this chapter deals with the long nineteenth century. It is followed by a section on the golden age of comparative law, which covers the period of the Weimar Republic (III). The 'dark age' of the 1930s and the first half of the 1940s will be referred to as the period of rupture and remorse (IV). The section on recovery encompasses post-war developments until the end of the cold war (V). The final section of this chapter focuses on the attempts to unify the law and on the new approaches to comparative law which have gained in importance in the course of the Europeanization of private law (VI).

\section{The Long Nineteenth Century}

The 'long nineteenth century' covers the period between 1789 and World War I (1914-18). Historians first coined this large-scale narrative to stress the importance of the French Revolution and to characterize the whole nineteenth century as a response to the revolutionary ideas which launched Europe into modern times. Obviously, the century is also crucial for the development of modern legal systems as well as modern legal science. The growth of comparative law - seen both as a method and as a field of research-also falls into this long century.

\section{Philosophical and Political Traditions}

The great codifications around 1800, that is, the Allgemeines Landrecht (Prussia, 1794), the Code civil (France, 1804), and the Allgemeines Bürgerliches Gesetzbuch (Austria, 18i1) can be regarded both as the end of the Age of Enlightenment and as the beginning of the 'Age of Comparison', which was Nietzsche's suggested label for the nineteenth century. The 'lost unity of natural law' 1 'made legal comparison between different laws not only possible, but also necessary. Thus, thanks to its

1 Anne Peters and Heiner Schwenke, 'Comparative Law beyond Post-Modernism', (2000) 49 ICLQ 800,803 . 
philosophical premises and its deductive method, Natural Law had been focusing on common and general principles. The legal diversity of the recently adopted codes enabled comparison which, however, did not merely follow a purely scientific motivation. In the eyes of contemporaries, those codifications not only represented the glory and triumph of modern and rational law making, but could also be viewed as the spectre of the liberal agenda of a bourgeoisie, which demonstrated its explosive potential in the French Revolution.

Neither Germany nor Switzerland represented unified units in the first half of the nineteenth century, nor did they have a unified law at that time. The territorial entities such as, for example, Prussia, Bavaria, Württemberg, or the Swiss cantons used to have laws of their own. In some French-occupied territories, French revolutionary laws became effective automatically; in others, they were introduced by choice, either tel quel or in a modified version, such as the Badisches Landrecht (1810), which was an adaptation in German of the Code civil. In the aftermath of the Vienna Congress in 1815, any interest in the French Code pénal and the Code civil corresponded not only to the actual territorial scope of those codifications, but also to the political preferences of liberal scholarship prevailing at that time. Consequently, the Code civil was retained in some Swiss cantons, for example, Geneva and Vaud, as well as in Baden. By way of contrast, conservative scholars and politicians were happy to overthrow the revolutionary heritage, with its dangerous ideas of freedom, èquality, and fraternity, as soon as the French occupation had come to an end and the return to a pre-revolutionary society seemed possible. The rather aristocratic and restorative cantons of Bern, Solothurn, and Lucerne in Switzerland favoured the Austrian Allgemeines Bürgerliches Gesetzbuch, against the background of Metternich's conservative political regime.

Last, but not least, the famous dispute between Friedrich Carl von Savigny and Anton Friedrich Justus Thibaut on the necessity of a codification for Germany can be mentioned as the most outstanding example of the impact of political preferences. Thibaut, holding the chair of Roman law at the liberal University of Heidelberg, argued in favour of a uniform code, with a Natural law basis, as an instrument of German unification. He stressed the importance of a better knowledge of foreign laws, and he was soon supported by the so-called Heidelberg School and the first journal of comparative law, which was founded in 1829: the Kritische Zeitschrift für Gesetzgebung und Rechtssetzung des Auslandes, edited by Karl Josef Anton Mittermaier and Karl Salomo Zachariae von Lingenthal.

Conversely, Savigny and the Historical School corroborated their aversion to a German Civil Code by reference to the 'shallow philosophy' of Natural Law with its 'infinite arrogance' - an aristocratic hostility to the presumed dangers of egalitarian ideas. Many scholars of comparative law are astonished that the Historical School was unwilling to take foreign law into consideration. In fact, the Romantic idea of a Volksgeist as the source of every nation's law was not, as such, opposed to empirical observation, which could have verified (or falsified) any theoretical 
assumptions. Therefore, ignoring contemporary foreign law was not only.a scientific choice; it also demonstrated a disapproval of liberal thought patterns and liberal scholarship in idealizing the Ancient Roman World in an ahistoric way.

Political preferences had an impact on philosophical orientation as well. Whereas the Historical School was influenced by romantic philosophers such as Herder, early comparatists instead referred to Hegel and a universalistic conception of law and history. Thus, Eduard Gans published his work on the law of succession in 1824 as a contribution to a universal history of law. ${ }^{2}$ Anselm von Feuerbach elaborated drafts of a Bavarian Civil Code (1808) and a Bavarian Penal Code (1813), both based on the French codes, but with a strong claim to legal universalism and strongly influenced by Hegel's philosophy.

However, all these promising attempts at comparative law completely disappeared by the middle of the nineteenth century under the all-dominant Historical School. ${ }^{3}$

\section{The Evolutionary Paradigm}

In the second half of the nineteenth century, an ethnological branch of legal science appeared under the name Vergleichende Rechtswissenschaft. It was based on a belief in legal progress, which was shared by a cross-section of the legal community. However, differences existed about its means. Names such as Georg Cohn, Franz Bernhöft, Albert Hermann Post, and Josef Kohler stood for the ambivalent attempt of defining the 'idea of law'4 by the description of different systems of law, present and past. This evolutionary paradigm assumed a hidden 'law' to be the actual originator of historical change, which could be gauged by observing 'primitive' tribal law as a mirror, at least partly, of one's own past. The Zeitschrift für vergleichende Rechtswissenschaft (Journal of Comparative Legal Science) was founded by members of that circle, and appeared for the first time in 1878. The programmatic foreword to the first issue contemplated the enlargement of the boundaries of legal science's and the overcoming of the national restriction which the Historical School had imposed on German legal science.

Although some authors are inclined to see one source for the development of modern comparative law in those ethnological studies, ${ }^{6}$ most scholars today deny

2 Eduard Gans, Das Erbrecht in weltgeschichtlicher Entwicklung: Eine Abhandlung der Universalrechtsgeschichte (4 vols, 1824-34).

3 See Konrad Zweigert and Hein Kötz, Einführung in die Rechtsvergleichung (3rd edn, 1996), 56. English translation under the title An Introduction to Comparative Law by Tony Weir (3rd edn, 1998), 58.

${ }^{4}$ Franz Bernhöft, 'Über Zweck und Mittel der vergleichenden Rechtswissenschaft', (1878) 1 Zeitschrift für vergleichende Rechtswissenschaft 1, 37.

${ }^{5}$ Ibid 2.

6 Otto Sandrock, Über Sinn und Methode zivilistischer Rechtsvergleichung (1966), 14. 
the importance of that school of thought or even ignore it completely. In fact, the careless accumulation of heterogeneous sources, the imprudent use of different methods, and the combination of observations and purely speculative thoughts, make it difficult to appreciate the work of those authors. This becomes all the more apparent when we consider an article by Josef Kohler, in which he admitted, selfcritically, the mistakes committed by him and others and the lack of both scientific precision and reflection. ${ }^{7}$ But instead of abandoning what he referred to as 'wild products of speculation', Kohler himself, in the same article, continued to engage in further such speculations.

\section{Legislative Comparative Law}

Despite the dominance of the Historical School, another branch of modern comparative law emerged during the second half of the nineteenth century which may be referrred to as legislative comparative law. In Germany, intensive comparative studies preceded the elaboration of several specific commercial statutes, which became necessary as a result of the development of trade and industry, for example, the Allgemeine Deutsche Wechselordnung (General German Bills of Exchange Act 1848), the Allgemeines Deutsches Handelsgesetzbuch (General German Commercial Code 1861), and the Geschmacksmusterrecht (Registered Designs Act 1878), as well as statutes on company law such as the Aktiengesetz (1870 and 1884). The preparatory work not only focused on the various laws prevailing in Germany at the time, but for the first time also encompassed other European Commercial Codes, such as those of France and the Netherlands, as well as sometimes even English law. Comparative law also played a prominent role in preparing the Konkursordnung (Insolvency Act 1881) and the Zivilprozessordnung (Civil Procedure Act 1880).

The two great Civil Codes at the dawn of the twentieth century, the German Bürgerliches Gesetzbuch (1900) and the Swiss Zivilgesetzbuch (1912), which unified private law in the German Reich and in Switzerland respectively, were firmly based on comparative research. In accordance with the aim of unification, the startingpoints were the particular laws of the Länder (in Germany) and the Cantons (in Switzenland). Thus for Eugen Huber, who may be called the father of the Swiss codification, comparative legal science had the task of 'stating the differences, comparing what is lying apart, emphasizing commonalities, investigating the reasons for the differences, and revealing the usual lines of development'. ${ }^{8}$ Likewise, the preparatory works for the German Civil Code show that comparative efforts were primarily focused on the ius commune of the nineteenth century as

7 Josef Kohler, 'Zur Urgeschichte der Ehe', (1897) 12 Zeitschrift für vergleichende Rechtswissenschaft $187,203$.

${ }^{8}$ Eugen Huber, System und Geschichte des schweizerischen Privatrechtes (vol I, 1886), 3. 
well as the specific laws of the various German Länder. However, foreign laws did not go unnoticed by the creators of the two codes, the main sources of comparison being the existing Natural law codifications of Austria, France, and Prussia. Last but not least, the new codes influenced each other to a certain degree in various fields. The German Civil Code, furthermore, had a considerable impact on the amendments to the Austrian Civil Code; from 1914 to 1916, three Teilnovellen were enacted, relying heavily on German solutions.

Although this seems to be a success story for comparative law, we must not forget that the German Bürgerliches Gesetzbuch is a product of the nineteenthcentury Historical School and the conceptual jurisprudence (Begriffsjurisprudenz) generated by it. Doctrinal considerations often prevailed over pragmatism. One notable example was the conception of a 'general part' of the Civil Code, which purported to create general rules that could be applied to all parts of private law, from the law of obligations to property law, family. law, and the law of succession. Gustav Radbruch therefore famously characterized the Bürgerliches Gesetzbuch as being more the cadence of the nineteenth century than the upbeat to the twentieth century. This was despite the promising and symbolically chosen date of 1 January 1900, upon which the new code was to enter into force.

In the context of a history of comparative law in Germany, however, the year of 1900 is not generally associated with the entry. into force of the Bürgerliches Gesetzbuch, but rather with the first World Conference of Comparative Law in Paris, often identified as the cradle of modern comparative law. The organizer of that conference, Raimond Saleilles, and the principal speaker, Edouard Lambert, expressed their hope that the use of the comparative method would finally lead to a droit commun de l'humanité civilisé, a unified law for the entire civilized world. This ambitious aim stood in stark contrast to the limited scope of comparison. Only statutory law was deemed to be comparable, thus confining the whole undertaking to continental law.

\section{Early Stages of Institutionalization}

Evien before the Paris Congress, German comparative lawyers had formed associations and founded comparative law journals in what may be called a process of institutionalization of comparative law.9 In 1893-94, first the Gesellschaft für vergleichende Rechts- und Staatswissenschaft (Association for Comparative Legal and Politcal Science) and then-initiated by Felix Meyer-the Internationale Vereinigung für vergleichende Rechtswissenschaft und Volkswirtschaftslehre (International Association for Comparative Legal Science and Political Economics) were

9 See Léontin-Jean Constantinesco, Rechtsvergleichung (vol I: Einführung in die Rechtsvergleichung, 1971), $132 \mathrm{ff}$. 
founded. The latter focused on 'our European-American World Culture'.10 The application of the comparative method on a historical and ethnological basis, mainly represented by Josef Kohler, was not to be neglected, although it was soon to lose popularity. From 1895 onwards, the association published a yearbook ${ }^{11}$ that was supplemented in 1902 by a monthly journal. ${ }^{12}$ The association had a genuinely international orientation, having not only close contacts to corresponding societies abroad, but also members from numerous countries. Highlights in the history of the association were conferences in Heidelberg in 1911 and Berlin in 1914, where the twentieth anniversary was celebrated by a gathering of 200 members, friends, and sponsors. ${ }^{13}$ Comparing the state of comparative law with that twenty years previously, Meyer, as president of the association, drew an overly optimistic picture on the very eve of World War I:14 'How different the situation is today, at a time when the internationalization of law has made enormous progress, no statute is prepared without the assistance of comparative law. ... Indeed, spring has come, also in Germany'.

Apart from the activities of the International Association, further endeavours enhancing the importance of comparative law can be encountered, such as the establishment of the journal Rheinische Zeitschrift für Zivil-und Prozessrecht (1909) that replaced the former Zeitschrift für Deutsches Bürgerliches Recht und französisches Civilrecht (1869). It counted Josef Kohler and Ernst Rabel among its editors.

World War I ended the early optimism and some ambitious projects, such as that of a German commentary on English law. Although comparative law was not held in high esteem during the war through being associated with an interest in the laws of the enemies, the process of institutionalization nevertheless continued at university level. As early as 1914, an Institut für Internationales Recht was founded in Kiel, to be followed by the famous Institut für Rechtsvergleichung in Munich in 1916, which, in turn, became the model for all later foundations, such as the Seminar für wirtschaftliche und rechtsvergleichende Studien at the University of Heidelberg in 1917, the Seminar für englisches Recht in Würzburg, the Seminar für deutsches und nordisches Recht in Hamburg, both in 1919, and finally the Universitäres Institut für Auslands- und Wirtschaftsrecht in Berlin in 1920.

The Versailles Treaty ended the 'long nineteenth century'. At the same time, the political consequences of the war laid the ground for a new era of comparative law, closely linked to the name of Ernst Rabel, who was to influence comparative law more than any other person throughout the twentieth century.

: 10. Elmar Wadle, Einhundert Jahre rechtsvergleichende Gesellschaften in Deutschland (1994), 32.

11 Franz Bernhöft and Felix Meyer (eds), Jahrbuch der Internationalen Vereinigung für vergleichende Rechtswissenschaft und Volkswirtschaftslehre (vol I, 1895).

12 Mitteilungen der Internationalen Vereinigung für Rechtswissenschaft und Volkswirtschaftslehre (vol I, 1902).

13 Wadle (n 10), $40 . \quad 14$ See Wadle (n 10), 41. 


\section{A Golden Age (1919-1933)}

\section{The Weimar Republic and the Pre-eminent Influence of Erinst Rabel}

The real flourishing of comparative law in Germany only began with the work of Ernst Rabel. ${ }^{15}$ He was born on 28 January 1874 in Vienna. All of his grandparents had been of the Jewish faith; his parents belonged to the Catholic church. Ernst Rabel was raised as part of the contemporary Viennese society with its conservative values, enjoying piano lessons with the old Anton Bruckner. After having completed his studies in his home town, Rabel worked as an attorney for a short while, but soon returned to the university, completing his second doctorate (Habilitationsschrift) in Leipzig in 1902 under the supervision of Ludwig Mitteis. Even this early work on the seller's liability for defects in title ${ }^{16}$ took account of the comparative dimension, but its focus was historical. In 1906, Rabel became a full professor and judge in Basel. In 1910 he went to Kiel, but left again in 1911 to go to the University of Göttingen. During those early years, Rabel's publications were mainly in the fields of Roman law and juristic papyrology. But he also argued, for instance, that the newly adopted rules of the German Civil Code on breach of contract, centred on the notion of 'impossibility', were based upon misunderstandings reflecting 'Windscheid's pseudo-romantistic doctrine'.17

In the middle of World War I, in 1916, Rabel moved to the University of Munich. By granting him more money to found an Institute of Comparative Law, Bavaria prevailed over the University. of Frankfurt. This fact sheds light both on the early reputation of Ernst Rabel and on the importance which, at the time, was attributed to the emerging discipline of comparative law.

The practical use of comparative law and the need for comparative research soon became visible with the Versailles Treaty of 1919, which had a deep impact not only on public, but also on private, law. As Rabel emphasized, the treaty had been worked out by lawyers of the coalition that had won World War I, using terminology based upon Anglo-American or French law, without any attempt to pay attention to different conceptions of German law and legal practice. ${ }^{18}$ To Rabel,

15 See Gerhard Kegel, 'Ernst Rabel-Werk und Person', (1990) 54 RabelsZ 1; Rolf Ulrich Kunze, Ernst Rabel und das Kaiser-Wilhelm-Institut für ausländisches und internationales Privatrecht 1926-1945 (2004); Timo Utermark, Rechtsgeschichte und Rechtsvergleichung bei Ernst Rabel (2005).

16 Ernst Rabel, Die Haftung des Verkäufers wegen Mangels im Rechte (1902).

17. See Ernst Rabel, 'Die Unmöglichkeit der Leistung. Eine kritische Studie zum Bürgerlichen Gesetzbuch' (1907), in Hans G. Leser (ed), Ernst Rabel, Gesammelte Aufsätze, vol I: Arbeiten zum Privatrecht (1965), 1, 26.

18 Ernst Rabel, 'Rechtsvergleichung vor den Gemischten Schiedsgerichtshöfen' (1923), in Hans G. Leser (ed), Ernst Rabel, Gesammelte Aufsätze, vol II: Arbeiten zur internationalen Rechtsprechung und zum internationalen Privatrecht (1965), 50, 53. 
a man used to comparative legal thinking, it was obvious that a real understanding of the Treaty was only possible by a truly comparative method. Furthermore, the need for basic research became obvious. Again, Rabel's vision was far ahead of its time, compared to the majority opinion of German legal scholarship.

Rabel's famous speech on the aims and purposes of comparative law in $1924^{19}$ has been called the 'foundational text of modern comparative law'.20 In fact, the speech is often cited and used as an example of Rabel's functional approach. He disapproved of the naïvity displayed in the comparison of isolated statutory rules, which were not considered in their context. He argued that the preoccupation with statutory law was not conducive to a full understanding of a legal system.

Instead of using a foreign legal system as a quarry, comparative law research should analyse not only the individual rules, but also the problems to which they refer and the solutions which they propose. ${ }^{21}$ It should take into account 'the law of the whole world, past and present, and everything that affects the law, such as geography, climate and race, developments and events shaping the course of a country's history . . .22 The functionalist method was to take real life problems as its starting point; and the new science of comparative law, according to Rabel, was to have the same aim as all other sciences: to promote knowledge and understanding. ${ }^{23}$ This set the course for the further development of comparative law. One result of that programmatic foundation was the 'discovery' of the common law as a necessary object of comparison.

Still, however, Rabel's speech addressed an audience of practising lawyers and not of legal scholars. The focus was therefore on the practical importance of comparative law. Rabel stressed the political difficulties of the post-war period, he deplored the lost influence of German legal science, and he stressed the danger of its isolation as a result of the Versailles Treaty. ${ }^{24}$ Twenty years later, in 1954, Rabel looked back somewhat ambivalently:

A comparative lawyer is exposed to be distrusted alternatively as a nationalist or as an antinationalist. 'A sound national law develops like a sound human being only in a social common life with the fellow others.' I must confess I underestimated for a long time the full bearing of this truth. Today I repeat that if all lawyers of the world knew it and would take it to heart, new hopes would arise-immense hopes for our often challenged and just now seriously shaken faith in justice. ${ }^{25}$

19 Ernst Rabel, 'Aufgabe und Notwendigkeit der Rechtsvergleichung' (1924), in Hans G. Leser (ed), Ernst Rabel, Gesammelte Aufsätze, vol III: Arbeiten zur Rechtsvergleichung und zur Rechtsvereinheitlichung (1967), 1.

${ }^{20}$ Kunze (n 15), $20 . \quad{ }^{21}$ Rabel (n 19), 1,3.

22 Ibid $5 . \quad 23$ Ibid 6.24 Ibid 18.

25 Ernst Rabel, 'Vorträge. Unprinted lectures 1954', (1986) 50 RabelsZ 282, 283. 


\section{The Kaiser-Wilhelm Institutes}

The political situation in Germany after World War I and its legal implications played an important role in the establishment of the first independent institutes of comparative law not affiliated with an existing university. The Union of German Industry founded the Institut für ausländisches Recht beim Reichsverband der deutschen Industrie. The aim of re-establishing the international trading relationships which Germany had enjoyed before the war had to be supported by the necessary knowledge of international instruments and foreign law. The first director of the Institute was Felix Meyer, who strongly stressed its practical function. When he died in 1925, he was followed by Josef Partsch, who attempted to shift the focus to academic research. ${ }^{26}$ Both Meyer and Partsch were close friends of Ernst Rabel, and Partsch was involved in the first plans to found a major institute of comparative law in Berlin, ${ }^{27}$ where all the ministries and the important associations of German industry were situated.

In December 1924, the Kaiser-Wilhelm-Gesellschaft agreed to establish an Institute of Public International Law in Berlin, with Victor Bruns as its first director. The Institute was to be financed by the Kaiser-Wilhelm-Gesellschaft, the Reich, and members' contributions. Considering that the importance of the Versailles Treaty extended to private law matters, the new Institute was first intended also to conduct research on international private law and the trade law. ${ }^{28}$ That idea was soon abandoned in favour of an independent institute. In the meantime, Rabel had been offered a chair at the University of Berlin, succeeding Josef Partsch who had died in 1925 at the age of $42 .{ }^{29}$ The Kaiser-Wilhelm-Gesellschaft made the autonomy: of the new institute a condition of Rabel's nomination, and when Rabel accepted the post, the Kaiser-Wilhelm-Institut für ausländisches und internationales Privatrecht was established in Berlin in 1926 and housed in the old castle in the centre of Berlin, next door to the Institute for Public International Law. It built up an extensive library as a necessary basis of its work. By 1932 it contained more than 200,000 volumes, including the largest collection of American legal materials and legal literature outside the United States. ${ }^{30}$

Also as a judge, Rabel faced the difficulties arising not only from the Versailles Treaty, but also from the war and its economic consequences in general. He was a member of the German-Italian Arbitral Tribunal in 1921 and served as a member of the Permanent International Court of Justice in The Hague from 1925 to 1928 .

26 On Partsch, see Rudolf Meyer-Pritzel, 'Der Rechtshistoriker und Pionier der modernen Rechtsvergleichung Josef Partsch (1882-1925)', (1999) > Zeitschrift für Europäisches Privatrecht 47 ff.

27 Wadle (n 10), $56 . \quad 28$ Kunze (n 15), 48. 29 Wadle (n 10), 55.

30 See Max Rheinstein, 'In Memory of Ernst Rabel', (1956) 5 AJCL 185. 
The Union of German Industry expected to be able to make practical use of the new Institute, which was entirely to replace its own Institut für Auslandsrecht. In exchange for financial contributions, German firms had access to the legal opinions produced by the Institute. Max Rheinstein, one of Rabel's early collaborators, directly linked the high quality of the work done by Rabel and his staff to the German successes before international courts of law. ${ }^{31}$ Nevertheless, Rabel tried to place the Institute's main focus on basic research. It was predominantly the German and international community of legal scholars who were to benefit from this type of research. To further this aim, Rabel established a comparative law journal, edited within the Institute, which was not only to provide the necessary information about different countries and legal subjects, but also to be a main source of reference for international comparative legal science.

The Zeitschrift für Ausländisches und Internationales Privatrecht first appeared in 1927. It replaced not only the former journals of Blätter für vergleichende Rechtswissenschaft und Volkswirtschaftslehre and Auslandsrecht, but also the Rheinische Zeitschrift fiur Zivil- und Prozessrecht. Rabel featured as its main editor. He later described the aims of the review and the difficulties encountered as follows: ${ }^{32}$

It had more than a thousand pages of big size every year and was entirely either worked on or supervised by the institute. I had laid much stress, from the beginning, on an ample and reliable publication of materials, that is, an annual survey of the enactments, decisions, literature and business forms of the important countries. I wanted them reported as quickly, as precisely and as comprehensively as possible, having complained myself often that all endeavours of such kind either came too late or were too vague. And I thought indeed that the first task of such an institute, with its skilled and paid staff, was to collect the facts, a task too hard and annoying for the single student but indispensable for theory and practice.

From 1928 onwards, the Institute figured as the editor of the series Beiträge zum ausländischen und internationalen Privatrecht, which published monographs focusing mainly on Anglo-American law. Nevertheless, the review continued to publish long studies on selected problems, among them the first volume of Rabel's monumental study on the law concerning the sale of goods ${ }^{33}$ in 1936.

\section{Sale of Goods}

From 1927, Ernst Rabel served as a member of the Board of the Institute for the Unification of Private Law in Rome. This Institute had been set up in 1926 as an

31 Max Rheinstein, 'Ernst Rabel', in Rechtsvergleichung und internationales Privatrecht, Festschrift für Ernst Rabel (vol I, 1954), 1, 2.

32 Rabel (n 25), 298.

33 Ernst Rabel, 'Das Recht des Warenkaufs, eine rechtsvergleichende Darstellung', Sonderheft der Zeitschrift für ausländisches und internationales Privatrecht (1936). 
auxiliary organ of the League of Nations. It had been initiated by the Italian Government under Benito Mussolini, who was endeavouring to found an institution which was to have members of international standing and so a worldwide reputation.

In 1929, Rabel initiated the project of unification of the law concerning the sale of goods, arguing that this subject, with its far-reaching international implications, would be most suitable for that purpose. In several articles, all published in the Institute's review, Rabel tried to promote the idea and the contours of the project. Rabel and the staff of the Berlin. Institute were to furnish the necessary basic research. Rabel's study on the sale of goods is the first attempt to give a comprehensive assessment of the law of sales, based on a truly comparative functional method. After a general discussion of the scope and the aims of the unification of sales law, he laid down the principles concerning the formation of sales contracts, the general duties arising out of this type of contract, as well as the duties of the seller. Further topics such as the duties of the buyer, the seller's liability for nonconformity of the goods, the passing of risk, as well as secured transactions, were to be left to another special issue of the Institute's journal. As a result of Rabel's expulsion from the Institute and from Germany, however, this did not appear during his lifetime, but was published only in 1958.

Rabel's work provided the intellectual foundations for the unification of international sales law. In 1929, Rabel delivered the famous 'Blue Report' to the Institute's Council in Rome. ${ }^{34}$ Soon thereafter, a committee was established with members from the English, French, Scandinavian, and German legal systems; it published the first draft of a Uniform Sales Law in 1935. Due to the political situation of the time, the idea was not pursued any further, but was only resumed by the Hague Conference. It was on the basis of Rabel's work that the (Hague) Uniform Law on the Sale of Goods and the Uniform Law on the Formation of Contracts for the International Sale of Goods were passed in 1964. These uniform laws, in turn, were to become the predecessor of the United Nations Convention on Contracts for the International Sale of Goods (CISG), adopted at the Vienna Conference in 1980 .

The list of persons whose contribution was acknowledged in the foreword of Das Recht des Warenkaufs of 1936 reads like a 'Who's Who' of leading scholars in post-war Germany and the United States, especially in comparative law. To name but a few: Friedrich Kessler, Ludwig Raiser, Max Rheinstein, Eduard Wahl, Ernst von Caemmerer, Arwed Blomeyer, Fritz Korkisch, and Konrad Duden. They had all been assistants at the Institute, which in its heyday had been the intellectual home of more than forty young scholars.

34 Ernst Rabel, 'Rapport sur le droit comparé en matière de vente', in idem, Gesammelte Aufsätze, vol III (n 19), 381 . 


\section{Rupture AND Remorse (1933-1950)}

In general presentations on legal history, the story of the 'dark age' of the Nazi period in Germany is generally told very quickly or even left out altogether. The section on the history of comparative law in the standard Introduction to Comparative Law ${ }^{35}$ ends with the optimistic claim that Rabel's functional method had ultimately come to be accepted for comparative law worldwide - without even mentioning that Rabel was forced to leave the Institute, his chair at the University of Berlin, and the editorial board of the Institute's review. In recent years, however, an extensive amount of research about the Nazi period has been undertaken, ${ }^{36}$ which permits the following assessment.

\section{The Policy of Gleichschaltung}

The German notion of Gleichschaltung describes the process by which the Nazi regime successively established control over public life in Germany. This was not only enforced from the top down; it was also a bottom-up process, which the British historian Ian Kershaw refers to as 'working towards the Führer'. With this notion he attempts to characterize Hitler's personalized form of rule, which invited radical initiatives from below and offered such initiatives backing, so long as they were in line with his broadly-defined goals. This promoted ferocious competition at all levels of the regime. ${ }^{37}$ Kershaw's account can also be helpful to describe the attitude of German legal science.

The ever-increasing incidence of civil unrest and riots was evidence of the difficulties of the late Weimar Republic. The universities too were affected. When Hitler was appointed as Chancellor of the Reich on 30 January 1933, the majority of the organized student body had already become members of the National Socialist student organization, but only a small minority of law professors openly sympathized with Hitler's party. ${ }^{38}$ However, the National Socialist Rechtswahrerbund-literally: union of professors of the law-already comprised 30,000 members by October 1933, compared with only 1,400 members in January, ${ }^{39}$ Rabel was the Dean of the law faculty in Berlin in the winter term of 1932-33, but he resigned from this

${ }^{35}$ Zweigert and Kötz (n 3), $47 \mathrm{ff}$ (48 ff of the English translation).

36 See, most recently, Reinhard Zimmermann, "Was Heimat hieß, nun heißt es Hölle" ', in Jack Beatson and Reinhard Zimmermann (eds), Jurists Uprooted: German-Speaking Émigré Lawyers in Twentieth-Century Britain (2004), I ff (with comprehensive references).

37 Ian Kershaw, Hitler 1889-1936: hubris (1998), 530.

38 Bernd Rüthers, Geschönte Geschichten-Geschonte Biographien, Sozialisationskohorten in Wendeliteraturen (2001), 35 .

39 Ibid 45. 
position prematurely; his successor was Ernst Heymann, the director of the Institut für Auslands- und Wirtschaftsrecht. ${ }^{40}$ There were fifteen chaired professors in the Berlin faculty, five of whom were to be dismissed because they were 'non-Aryans', to use the Nazi terminology. Heymann was not willing to support his Jewish colleagues; on the contrary, along with colleagues such as Carl Schmitt, Carl August Emge, and Graf von Gleispach, he supported the establishment of a National Socialist school of thought. Gleispach became Dean of the faculty in 1935. Heymann had tried to persuade Martin Wolff and Rabel to leave the faculty, but both of them refused; so Gleispach reported their names to the Ministry of Education with an appeal to expel them for being a 'heavy burden for the German student body' and an 'obstacle for the implementation of the National Socialist spirit'. ${ }^{41}$ Then, in October 1935, Rabel, like so many of his 'non-Aryan' colleagues before him, was forced to leave the University.

The Kaiser-Wilhelm-Institut für ausländisches und internationales Privatrecht was also forced to face the consequences of the National Socialist regime. Many of its scholars left Germany because they were Jewish. Max Rheinstein had won the prestigious Rockefeller scholarship and went to New York in 1933. This was both the chance to leave and the reason for his expulsion from the Institute and the University, which he was unable to prevent. Friedrich Glum, the president of the Kaiser-Wilhelm-Gesellschaft, and a member of the Berlin faculty, argued that 'non-Aryan Rockefeller scholars' were no longer to be hired. ${ }^{42}$ Of all the emigrants, Rheinstein seems to have been one of the most fortunate. He was young; moreover; he was a specialist in comparative law and well acquainted with the common law. In 1935, he secured a position on the faculty of the University of Chicago Law School. 43 Friedrich Kessler left Germany in 1934 at the age of 33. As a specialist in American law he, too, had relatively favourable conditions for a new start abroad: he went to Yale and Chicago, returned to Yale and-after his retirement from Yale-finally moved to Berkeley. ${ }^{44}$

After his forced retirement from the university, Rabel was still allowed to act as the Director of the Institute until 1937, when Heymann succeeded him. The protocol of the meeting of the chairman of the Institute's governing body and a representative of the Ministry of Science and Education stated: ${ }^{45}$

40 For details on the change in the Berlin law faculty, see Anna-Maria Gräfin von Lösch, Der nackte Geist: die Juristische Fakultät der Berliner Universität im Umbruch von 1933 (1999), $156 \mathrm{ff}$.

41 See Kunze (n 15), 64.

42 Gräfin von Lösch (n 40), 214.

43 Mary Ann Glendon, 'The Influence of Max Rheinstein on American Law', in Marcus Lutter, Ernst C. Stiefel, and Michael H. Hoeflich (eds), Der Einfluss deutscher Emigranten auf die Rechtsentwicklung in den USA und in Deutschland (1991), 171, 172.

44 Herbert Bernstein, 'Friedrich Kessler's American Contract Scholarship and its Political Subtext', in Lutter et al (n 43), 87 .

45 Kunze (n 15); 166. 
We arrive at the following conclusion: Professor Rabel, whose merits concerning the Institute are recognized by the Ministry, has to resign from his position as head of the Institute. It is intolerable for the State that a person presides over the Institute who must be superannuated as a result of the Nuremberg Laws.

The name of Ernst Rabel was to disappear from the journal as well: 'Henceforth, only the Director of the. Institute shall be named on the Journal, which will make it easier for Prof. Rabel to accept the embarrassment of the disappearance of his name'. ${ }^{6}$ Consequently, the Zeitschrift für Ausländisches und Internationales Privatrecht began to appear under the name of Ernst Heymann.

Not until the very eve of World War II, in March 1939, did Rabel leave Germany for the United States. He first went to Philadelphia and subsequently became a visiting lecturer at Ann Arbor, Michigan, where he devoted himself to work on his second monumental work, The Conflict of Laws. However, Rabel, by then in his late sixties, did not really flourish in the United States. His study on the law of sales was unknown there. Although he tried to adapt his own draft to the proposals of the Uniform Commercial Code, Karl N. Llewellyn did not intend to collaborate with the famous German professor whom he had met in Europe: some years before. ${ }^{47}$ The Dean of the Michigan Law School was to state many years later: 'We did not know who he actually was'.48 In Germany, his name disappeared not only from the journal of the Institute, but also from footnotes and bibliographies in legal scholarship. Walter Erbe did not even refer to Rabel when he published his article on the purpose of comparative law in the journal of the Institute in 1942.

Rabel's co-founder of the Munich Institute in 1916, Karl Neumeyer, had been forced to retire in 1934. In 1940, he had to sell off his entire library by auction. To escape imminent deportation, Neumeyer and his wife committed suicide in 1941.

\section{National Socialist Comparative Law?}

The Zeitschrift für Ausländisches und Internationales/Privatrecht continued to appear until 1942. A recent study on the Institute and its role during the Third Reich ${ }^{49}$ has shown that Ernst Heymann tried to give the Institute a new National Socialist profile. Although the journal maintained its basic structure, more and more book reviews began to focus, on the new trend in German legal scholarship. Not only the journal, but also the second International Conference of Comparative Law, which took place in The Hague in 1937, seemed to offer the German delegation a chance to promote National Socialist legal theories. The majority of assembled scholars welcomed the new regime and contributed to the attempts to

\footnotetext{
46 Ibid 167.

47. Bernhard Grossfeld and Peter Winship, 'Der Rechtsgelehrte in der Fremde', in Lutter et al (n 43), 197.

48 Ibid 190. $\quad 49$ Kunze (n 15).
} 
nazify German law. Wolfgang Siebert gave a lecture on the general change of the notion of contract, and came out in favour of the new view that regarded contract as an instrument of the 'people's' (völkisch) order. ${ }^{50}$

In 1968, Bernd Rüthers analysed the details of the legal change during the Third Reich. He demonstrated how German scholars were eager to 'work towards the Führer' by turning the existing German private law into an instrument of racist and anti-Semitic oppression. ${ }^{51}$. Although there was never a comprehensive system of National Socialist legal theory, but rather a vast diversity of different approaches, ${ }^{52}$ the new ideas were all centred on vague notions such as race, Volk, Führer, honour, or blood and soil. Authors such as Karl Larenz, Wolfgang Siebert, and Hans Dölle (who was to become Director of the Institute in the post-war era) advocated the transformation of the existing private law into an instrument of National Socialist ideology. ${ }^{53}$

Only: a few scholars stuck to the ideal of classical comparative legal scholarship. Ernst von Caemmerer, who was among the German members of the delegation at the above-mentioned Hague Congress in 1937, was an example. His lecture on the role of the media still reveals the differences in quality when compared to the Nazi ideas in the same field of law as they were advocated by another member of the delegation, Alexander Elster, in his lecture on copyright law. ${ }^{54}$ When Georg Dahm finally argued that the legal principle of nullum crimen sine lege in reality signified a renunciation of substantive justice, the German delegation revealed its complete isolation. Heymann reported that the Congress had been a success and that further participation of German scholars in international conferences would be usefulwithout being aware of the reality that Germany had lost her leading position in comparative law. Not being willing to collaborate, von Caemmerer was among the few who decided to leave the Institute. He refuised to accept a chair at the University of Rostock during the Nazi period and only resumed his plans for an academic career with a Habilitation after World War II. ${ }^{55}$

During the late 1930 s and the early 1940s the journal of the Institute and the Institute itself became more and more involved with the Nazi regime and its

${ }^{50}$ Wolfgang Siebert, 'Die allgemeine Entwicklung des Vertragsbegriffs', in Ernst Heymann (ed), Deutsche Landsreferate zum II. Internationalen Kongress für Rechtsvergleichung im Haag 1937 (1937), $199-215$.

${ }^{51}$ Bernd Rüthers, Die unbegrenzte Auslegung: zum Wandel der Privatrechtsordnung im Nationalsozialismus (1968).

52 See Michael Stolleis, Recht im Unrecht (1994), 32.

53 For Hans Dölle see eg 'Das deutsche bürgerliche Recht im nationalsozialistischen Staat', 1933 Schmollers Jahrbuch 649; idem, 'Vom alten zum neuen Schuldrecht', 1934 Deutsche Juristen-Zeitung 1017; idem, 'Die Neugestaltung des Deutschen Bürgerlichen Rechts', (1937) 4 Zeitschrift der Akademie für Deutsches Recht 359.

${ }^{54}$ See Kunze (n 15), 175.

${ }^{55}$ Albin Eser, 'Begrüssung zur Akademischen Gedenkfeier für Ernst von Caemmerer am 18. Februar 1987', (1987) 98 Freiburger Universitätsblätter 47, 48. 
ideology. Legal opinions were furnished not only to the government, but also to the National Socialist Party, and more and more articles which welcomed the attempts to change German private law into a völkische Ordnung were published. The new approach was not comparative in method; it was largely an exercise in selfpromotion, which aimed to show the rest of the world the superiority of the new ideology and its impact on the law. To this end, the German Rechtswahrerbund founded a new international association, the Internationale Rechtskammer in 1941; it was composed of members of the allied or occupied countries. Hans Frank, Imperial Minister without Portfolio, became chairman of the association. Frank had once attended Rabel's lectures in Munich; now he discredited traditional legal scholarship by speaking out against a formalistic and over-zealous approach to law. ${ }^{56}$ Despite the preponderance of shallow literature which served only to glorify Nazi ideology, there were still a number of publications emanating from the Institute which can be regarded, even today, as good examples of comparative research. Among them is Die Einwirkung des Krieges auf Verträge by Gerhard Kegel, Hans Rupp, and Konrad Zweigert, published in 1941,57 . which, in addition to German law, encompassed also French, English, and US law in particular.

One of the consequences of Heymann's collaboration with the Nazi regime was that the Institute was classified as kriegswichtig, or important for the purposes of the war. This is why the Institute, with its precious library, was evacuated from Berlin to Tübingen at the initiative of Konrad Zweigert and Hans Rupp in 1944 and was thus saved from destruction when the old castle in Berlin was bombed later in the same year.

The Institute for Foreign Private Law and Private International Law's twin sister, the Institute of Public International Law, managed to preserve much more of its independence, even though it was supposed to furnish the legal basis for German expansionist foreign policy..$^{58}$ Although its director, Bruns, had become a member of the Nazi legal association, he opposed the new Nazi tendencies in the field of international law. Despite having initially welcomed the policy of conquest, in the course of time the Institute developed a climate of resistance towards a regime which showed disdain for international law in general, and international humanitarian law in particular. A group of scholars later supported the armed resistance of 1944, among them Berthold Graf Schenk von Stauffenberg and Helmuth James Graf Moltke.

56 Hans Frank, 'Ansprache aus Anlass der Gründung der Internationalen Rechtskammer in Berlin vom 3. bis 5. April 1941', in Helmut Pfeiffer (ed), Tagungsbericht der Internationalen Juristenbesprechung aus Anlass der Gründung der Internationalen Reichskammer (1941), 103, 104.

57 Gerhard Kegel, Hans Rupp, and Konrad Zweigert, Die Einwirkung des Krieges auf.Verträge (1941).

58 See Ingo Hueck, 'Die deutsche Völkerrechtswissenschaft im Nationalsozialismus', in Doris Kaufmann (ed), Geschichte der Kaiser-Wilhelm-Gesellschaft im Nationalsozialismus (vol II, 2000), 490. 


\section{Continuity}

German legal scholarship and, with it, comparative law, remained devastated during the years immediately after World War II. The interruption was, however, brief, for very soon many academics who had been proponents of the new German legal culture were allowed to return to their chairs at German law faculties. This continuity is also to be seen in the history of the Kaiser-Wilhelm Institute. Heymann remained the director of the Institute until his death in 1946, when he was succeeded by Hans Dölle.

In 1949, the Institute was formally dissolved and re-established under the auspices of the Max-Planck-Gesellschaft (the successor of the Kaiser-WilhelmGesellschaft) as the Max-Planck-Instiut für ausländisches und internationales Privatrecht. While the Institute was to flourish, the personal fate of its founder, Ernst Rabel, was much less fortunate. ${ }^{59}$ In 1946 Dölle invited Rabel to join the Tübingen Institute. Rabel was indeed eager to come back to Germany, since he felt out of place in the United States. However, his return proved to be very difficult, not only for organizational reasons, but also because of a considerable reluctance on the part of the German scholarly community to welcome him among them. This in turn was largely due to the contemporary tendency to repress the shameful past and one's own personal and scholarly contribution to it. Still, Rabel was able to continue his work in the Tübingen Institute. In 1951 he finished the second volume of the law concerning the sale of goods, which he was able to present as a manuscript at the Hague Conference that had gathered to discuss the uniform law of international sales. The work was not published, however, until 1956, one year after his death.

The difficulties encountered by non-Nazi comparatists in post-war German law faculties can also be illustrated by Ernst von Caemmerer, whose comparative contributions were to have considerable influence on the development of German law. Von Caemmerer did not pass his Habilitation until after the war at the University of Frankfurt-on-Main under the supervision of Walter Hallstein. When the law faculty of Freiburg im Breisgau had to appoint a person for the chair for private law, commercial law, and conflicts of law, it first attempted to nominate scholars who were considered to be more senior, even if they had been been involved with Nazi ideology. It was only the military government which reversed the nomination lists and appointed Ernst von Caemmerer-against the will of the faculty. ${ }^{60}$

For a long time in post-war Germany the Nazi period tended to be hidden behind the phrase the 'dark years'; the cultural and academic elites attempted to live as though those twelve years had never happened. ${ }^{61}$ Compensation often

59 Kunze (n 15), 230 ff. $\quad 60$ Eser (1987) 98 Freiburger Universitätsblatter 49.

61 Michael Stolleis, Reluctance to Glance in the Mirror: The Changing Face of German Jurisprudence after 1933 and post-1945 (The Maurice and Muriel Fulton Lecture Series of the Law School, University of Chicago, 2001). 
remained at a symbolic level. Thus, in 1950, Rabel was made an honorary member of the newly founded Society of Comparative Law, and the Zeitschrift für Internationales und ausländisches Privatrecht was renamed Rabels Zeitschrift with effect from 1960 .

\section{ReCOVERY (1950-1989)}

\section{General Aspects and Institutionalization}

The revitalization of comparative law on an international level began in the late 1940s. In 1949, UNESCO gathered an organizing committee in Paris that was to establish an international association for comparative law; the committee consisted of eighteen leading scholars, among them Ernst Rabel. It set itself the task of 'organizing research, legal literature, and teaching in the field of comparative law as a means towards international understanding and peace': 62 a universalistic aim just as ambitious as the one announced at the Paris World Conference almost fifty years before. One of the suggestions was to establish national committees as the basis for the international association. In Germany Hans Dölle, Walter Hallstein, and Eduard Wahl were charged with the preparations. Finally, in 1950, the Gesellschaft für Rechtsvergleichung was established. It held its first conference in Tübingen and was presided over by Dölle. The association regarded itself as the direct successor of the Vereinigung für vergleichende Rechtswissenschaft und Volkswirtschaftslehre, which had ceased to exist in $1933 .{ }^{63}$ In 1950 , a German delegation was sent to the IIIrd International Congress of Comparative Law in London, and an impressive volume brought together the German contributions delivered at this conference. ${ }^{64}$ However, the association did not intend to become an independent research institution; its aim was limited to supporting and initiating projects. ${ }^{65}$ From its very beginnings, the association was divided into a number of sections according to the main branches of the law; thus, there were sections on comparative private law, comparative public law, comparative criminal law, comparative commercial law, foundational research, and even for comparative legal history and ethnological research. From time to time, new sections were added, such as those on intellectual property law and labour and social security law.

62 See Wadle (n 10), $77 . \quad 63$ Ibid 73.

64 Ernst Wolff (ed), Deutsche Landesreferate zum III. Internationalen Kongress für Rechtsvergleichung in London 1950 (1950).

65 Wadle (n 10), 79. 
The importance of research in comparative law at the universities began to increase in the aftermath of World War II. Institutes that had their origins in the time before Hitler's seizure of power, such as those in Munich, Heidelberg, and Frankfurt, were eager to re-establish the tradition. New institutes were also created, among them the Institut für ausländisches und internationales Privatrecht at the University of Freiburg. However, the most important projects of comparative law remained linked to the Max-Planck-Institut für ausländisches und internationales Privatrecht, which moved to Hamburg in 1956. The Institute for Comparative Public Law and Public International Law had been re-established under the auspices of the Max-Planck-Gesellschaft in Heidelberg.

Later, other Max Planck Institutes (MPI) were founded, partly as successors of earlier university institutes: the MPI for European Legal History in Frankfurt-onMain (1964), the MPI for Foreign and International Criminal Law in Freiburg (1966), and the MPI for Foreign and International Social Law in Munich (1980). Another important institution was the Deutscher Rat für Internationales Privatrecht (German Council for Private International Law), which was established in 1954 on Dölle's initiative. It is composed of two commissions and serves as an advisory body to the German government in the preparation of important statutes or conventions with an international element. It played a crucial role in the elaboration of the UN Convention on Contracts for the International Sale of Goods (CISG) in the 1970 s.

In the German Democratic Republic, the Institut für ausländisches Recht und Rechtsvergleichung was established in 1967 at the Akademie für Staats- und Rechtswissenschaft der DDR (Academy for Political and Legal Science of the German Democratic Republic) in Potsdam-Babelsberg. ${ }^{66}$ It was to furnish legal opinions to the Ministry of Justice concerning the unification of law between the socialist countries. Studies focusing on the comparison between socialist and capitalist legal systems were done either to stress the superiority of the socialist law, or to prepare or interpret internationally uniform law such as the CISG.

The institutionalization of comparative law in Austria and Switzerland did not begin until the late 1950s. Hans Köhler was the editor of the Österreichische Hefte für die Praxis des internationalen und ausländischen Rechts, which was published from 1956 to 1960. In 1960, an Association for Comparative Law was founded, followed by an Institute for Comparative Law at the University of Vienna. From 1960 onwards, the Institute and the Association edited the journal Zeitschrift für Rechtsvergleichung, which became the Zeitschrift für Rechtsvergleichung, internationales Privatrecht und Europarecht in 1991. Even today, no university institute of comparative law exists in Switzerland. However, there is the Swiss Institute of

\footnotetext{
${ }^{66}$ On the role of comparative law in that academy, see Akademie für Staats- und Rechtswissenschaft der DDR (ed), Die Rolle der Rechtsvergleichung in der Rechtswissenschaft, Rechtsausbildung und Rechtspraxis der DDR sowie in der ideologischen Auseinandersetzung (1982).
} 
Comparative Law in Lausanne, which was founded in 1982 as an independent entity of the Swiss administration. It prepares legal opinions on behalf of individuals and governmental agencies and has an impressive library on foreign and comparative law. The only journal that addresses comparative issues at all, although not as its main focus, is the Schweizerische Zeitschrift für internationales und europäisches Recht, which commenced publication in 1991.

\section{Methods and Fields of Interest}

\section{(a) Methodological Foundations}

In the 1950s, there was a general consensus that the functional method should be the basis of comparative research. Konrad Zweigert's famous inaugural lecture in 1949 on the subject of comparative law as a universal method of interpretation ${ }^{67}$ laid down the principles that were to rule comparative law for the years to come. Zweigert's call to use comparative law for the purposes of interpreting existing law was firmly based on the functional method. However, he deviated slightly from Rabel's approach by focusing on the need for a critical evaluation which searched for the best, rather than the prevailing, solution. Moreover, and somewhat overoptimistically, he suggested that not only law makers, but also courts, should bring comparative reflections to bear in their everyday work.

During the 1950 s and the 1960s, the functional method was enriched by embracing sociological considerations. This can be traced mainly to Josef Esser who, in his great work Grundsatz und Norm in der richterlichen Fortbildung des Privatrechts (1956), familiarized not only comparative lawyers in Germany but also German legal scholarship at large with the intricacies of American legal realism and sociological jurisprudence concerning judicial law making and law finding. On Zweigert's initiative, a group for socio-legal research was established at the Hamburg Max-Planck Institute in the 1970s, but its success was limited and the group was soon to be dissolved. Although some texts did include consideration of the sociological aspects of their topics, this was usually only at a superficial level and was more a result of pandering to modern trends than of a desire for truly interdisciplinary research. ${ }^{68}$

Although the theory of families of legal systems never attained as much importance in Germany as it did in France, ${ }^{69}$ German comparatists did attempt to identify

${ }^{67}$ Konrad Zweigert, 'Rechtsvergleichung als universale Interpretationsmethode', (1949/50) 15 Zeitschrift für ausländisches und internationales Privatrecht 5 .

${ }^{68}$ Michael Martinek, 'Wissenschaftsgeschichte der Rechtsvergleichung und des internationalen Privatrechts in der BRD', in Dieter Simon (ed), Rechtswissenschaft in der Bonner Republik: Studien zur Wissenschaftsgeschichte der Jurisprudenz (1994), 529, 552.

69 René David, Les grands systèmes de droits contemporains (1964). 
characteristic features of legal systems, or groups of legal systems, in order to distinguish them from each other. In 1961, Zweigert transferred the notion of 'style', as it was used in literature and in the fine arts, to the description of legal systems and he identified historical background and development, predominant modes of legal thought, especially distinctive institutions, the kind of legal sources and the ways of handling them, and the prevailing ideology as important factors for determining the 'style' of a legal system..$^{70}$ Looking back, this endeavour seems rather arbitrary and unfruitful. Thus, in the first edition of Zweigert and Kötz's Introduction to Comparative Law, published in $1971,{ }^{71}$ the style of the French legal family was characterized by the position of illegitimate children and by the famous provision of Art 340 Code civil (which was at that date still in force): 'La recherche de la paternité est interdite. ${ }^{72}$ Shortly thereafter, however, the French legislature abandoned this rule. This incident probably contributed to Zweigert and Kötz's abandoning the attempt to define typical stylistic factors for legal systems in the second edition of their work in 1984, although the concept, as such, was retained. ${ }^{73}$

It was generally understood that comparison presupposed comparability. Thus, even in 1949, Zweigert stressed the boundaries of comparative law, both concerning the areas of the law which could be subjected to the comparative method and the countries whose laws might be considered. Comparative studies were taken to be fruitful only for those areas that were not of a specifically national character. Family law or the law of succession thus remained largely excluded. Moreover comparison was limited to those legal systems 'that were more or less on the same cultural level as one's own'. ${ }^{74}$ This excluded the so-called primitive laws, religious laws, and also the laws of the socialist legal systems.

\section{(b) Fields of Interest}

During the 1950s; the main focus was on the law of obligations, with an ongoing special interest in the law of sales. Whereas the fields of interest were soon expanded, the reluctance to consider socialist legal systems was to persist. The reason for this was said to be the different function attributed to law in socialist systems. This approach received institutional support. Whereas the German Association of Comparative Law did not have any problem establishing a section on European Law in 1962, a proposal to set up another section dealing with socialist legal systems was rejected. ${ }^{75}$ However, institutes with a special focus on 'eastern

70 Konrad Zweigert, 'Zur Lehre von den Rechtskreisen', in 20th Century Comparative and Conflicts Law: Legal Essays in Honor of Hessel E. Yntema (1961), 42.

71 Konrad Zweigert and Hein Kötz, Einführung in die Rechtsvergleichung auf dem Gebiete des Privatrechts (vol I: Grundlagen, 1st edn, 1971, vol II: Institutionen, 1st edn, 1969).

72 Ibid, $\S 10$.

73 Konrad Zweigert and Hein Kötz, Einführung in die Rechtsvergleichung (2nd edn, 2 vols, 1984).

74 Zweigert, (1949/50) 15 Zeitschrift für ausländisches und internationales Privatrecht 13.

75 Wadle (n 10), 84. 
law' (Ostrecht) were established at universities; the subject-matter thus became a specialized field of study which remained outside the general comparative discourse. ${ }^{76}$ From 1968, the Institute for Eastern Law of the Freie Universität Berlin furnished a basis for research by editing the legal sources of socialist countries. ${ }^{77}$

A certain shift of focus concerning the legal systems studied by comparative lawyers can be observed during the 1950s. Much work after World War I had been centred on Anglo-American law. ${ }^{78}$ This interest continued after World War II; it was even fuelled by the influence of eminent German comparatist scholars who had predominantly emigrated to the United States and to England. ${ }^{79}$ Nevertheless, for a number of reasons, a special interest in French law became apparent by the middle of the 1950s. One reason for this was that the Saar area did not become a Land of the Federal Republic of Germany until 1957, after a period of formal autonomy, during which it had maintained strong economic and administrative links with France. Thus, it was only natural that at the new University of Saarbrücken, founded in 1948 in cooperation with France, comparison with French law was nurtured from the very beginning, the main advocate being Léontin-Jean Constantinesco. Consideration of French law was also forcefully promoted by Murad Ferid, who was the director of the Institute for Comparative Law at the University of Munich. A further, and probably the most important, reason was that the European countries began to come closer to each other, particularly after the formation of the European Economic Community (EEC) in 1957 with Belgium, the Netherlands, Luxembourg, France, Italy, and the German Federal Republic as its founding members. The influence of France, and of the countries influenced by French law and culture, was very significant in the EEC.

Until the 1990s, comparative law in Austria and Switzerland focused primarily on German law. This is due partly to the similarity of language and partly to the fact that a number of German scholars occupied chairs at law faculties in Austria and Switzerland. The reception of German ideas was not always a happy experience, since it occurred without much consideration of their background..$^{80}$ Two examples will demonstrate this. In its Code of Obligations, the Swiss law of delict is based on a so-called general provision, much inspired by Art 1382 of the French Code civil. However, when interpreting the provision of Art $41 \mathrm{OR}$, legal scholars and courts did not consider the legal developments in France since 1804, but heavily relied on the German Bürgerliches Gesetzbuch with its $\$ 823 \mathrm{I}$, where delictual liability is

76 Martinek (n 68), 563.

77 Osteuropa-Institut an der Freien Universität Berlin (ed), Quellen zur Rechtsvergleichung (1968 ff).

78. See, as one outstanding example, Fritz Kessler, Die Fahrlässigkeit im nordamerikanischen Deliktsrecht: unter vergleichender Berücksichtigung des deutschen und des englischen Rechts (1932).

79 See Lutter et al (n 43); Beatson and Zimmermann (n 36).

80 Ingeborg Schwenzer, 'Rezeption deutschen Rechtsdenkens im schweizerischen Obligationenrecht', in eadem (ed), Schuldrecht, Rechtsvergleichung und Rechtsvereinheitlichung an der Schwelle zum 21. Jahrhundert (1998), 59. 
based on the infringement of one of the specific rights and interests listed in this provision. This rather narrow list was adopted by Swiss legal scholars and courts in defining the requirement of unlawfulness in Art $4 \mathrm{I}$ I OR, thus effectively abandoning the very notion of a general provision and its Natural law heritage. Another, more recent, example is the Swiss reception of the notion of faktisches Vertragsverhälnis, that is, the idea that contracts are not always based on the intention of the contracting parties, but can also come into existence as a result of mere facts and behaviour. Very much in line with the anti-liberal thought patterns prevailing during the Nazi regime, this concept had been developed by Günter Haupt in his Leipzig inaugural lecture in $1941^{81}$ and was later, for some time, also espoused by Karl Larenz (though by few other German authors). ${ }^{82}$ Swiss literature, however, welcomed this principle, and in 1984 it even found its way into decisions of the Swiss Federal Tribunal. ${ }^{83}$ This was at a time when the principle had been abandoned in Germany, even by Larenz. ${ }^{84}$

\section{Comparative Law Scholarship in the Post-War Era: Some Highlights}

In the post-war years, comparative law seemed to flourish. Even in many doctoral dissertations reference to other legal systems could be found. More often than not, however, a truly comparative approach was lacking; instead, we merely find reports on foreign laws. Nevertheless, throughout this period, prominent comparative work was published, considerably influencing legal developments in Germany.

\section{(a) Comparative Law in General}

It must be mentioned at the outset that the late Konrad Zweigert and Ulrich Drobnig, who was to become one of his successors as Director of the Max Planck Institute in Hamburg, set up the International Encyclopedia of Comparative Law, a truly universal endeavour covering all areas of private law in seventeen volumes. The first fascicles were published in 1972; to date, the work is still in progress.

The most prominent contribution to comparative law, which is unequalled anywhere else in the world, is the introduction to comparative law by Konrad Zweigert and Hein Kötz, first published in $1969 .^{85}$ In 1977, Tony Weir's English translation

\footnotetext{
81 Günter Haupt, 'Über faktische Vertragsverhältnisse', in Festschrift der Leipziger Juristenfakultät für Heinrich Siber (vol II, 1943), 1.

82 Karl Larenz, 'Die Begründung von Schuldverhältnissen durch Sozialtypisches Verhalten', [1956] Nere Juristische Wochenschrift 1897.

83 BGE 110 II 244.

84 Karl Larenz, Allgemeiner Teil des deutschen Bürgerlichen Rechts: Ein Lehrbuch (7th edn, 1989), $\$ 28$ II.

85 See $n 71$.
} 
appeared, as a result of which the book also became a classic of comparative legal literature in the Anglo-American legal world. Another major scholarly contribution is the three-volume study by Léontin-Jean Constantinesco. ${ }^{86}$

Great services to the understanding of French law in Germany were rendered by Murad Ferid and later Hans Jürgen Sonnenberger, with their comprehensive work on French Private Law, ${ }^{87}$ the characteristic feature of which is its presentation of the French law according to the system of the German Civil Code.

\section{(b) Law of Sales}

The law of sales continued to be a matter of primary interest to German scholars in the aftermath of World War II, when the idea of the unification of international sales law was resumed. The discussions at the Hague Conference concerning the Uniform Law on the International Sale of Goods and the Uniform Law on the Formation of Contracts for the International Sale of Goods were closely followed by German comparatists, among whom Ernst von Caemmerer occupied a leading position. ${ }^{88}$ Hans Dölle was the first to edit a commentary on the Uniform Law on the International Sale of Goods in $1976 .{ }^{89}$ Although the Hague Conventions were not a success - they were implemented by only nine states - they served as a model for the work of the United Nations Commission on International Trade Law (UNCITRAL) concerning the United Nations Convention on Contracts for the International Sale of Goods (CISG), which was eventually adopted in Vienna in 1980.

The preparatory work of UNCITRAL in Germany was followed, and commented upon, by the Commission on the Law of Obligations of the German Council for Private International Law, chaired by Ernst von Caemmerer. His successor to the chair of the Institute of Foreign and Comparative Law at the University of Freiburg, Peter Schlechtriem, was a member of the German delegation to the Vienna Conference in 1980. He published a monograph on the CISG as early as $1981,{ }^{90}$ which was soon to be translated into English and later editions of which have now been translated into many other languages. In the 1990s, Schlechtriem started editing a commentary on the CISG that was to become one of the main authorities in this field.

86 Léontin-Jean Constantinesco, Rechtsvergleichung (3 vols, 1971-83).

87 Murad Ferid, Das französische Zivilrecht (2 vols, 1971); Murad Ferid and Hans Jürgen Sonnenberger, Das französische Zivilrecht (2nd edn, 1986).

88 See Ernst von Caemmerer, 'Internationales Kaufrecht', in idem, Gesammelte Schriften (vol I, 1968), 79; Ernst von Caemmerer, 'Die Haager Konferenz über die internationale Vereinheitlichung des Kaufrechts vom 2-25. April 1964', in ibid 97.

${ }^{89}$ Hans Dölle (ed), Kommentar zum einheitlichen Kaufrecht: die Haager Kaufrechtsübereinkommen vom 1. Juli 1964 (1976).

90 Peter Schlechtriem, Einheitliches UN-Kaufrecht (1981). 


\section{(c) Tort Law}

The intricacies of German tort law, which is strongly rooted in the nineteenth century, were at least partly brought to light by von Caemmerer's comparative studies in tort law, especially his masterpiece, Wandlungen des Deliktsrechts, ${ }^{91}$ where an intellectual link was established to negligence liability in the common law. Furthermore, von Caemmerer conducted fundamental research in the field of causation. Building upon Rabel's ideas, he introduced the central notion of Schutzzweck (protective ambit) into German law, using it as a means to limit liability in the same way as Anglo-American law specifies the scope of a duty of care.

The development of products liability was firmly based upon comparative research. After quite a number of studies on products liability had already been published, some of which supported the French regime of contractual liability, it was Werner Lorenz who provided the decisive impulse for the German development. His general report on the liability of producers of goods ${ }^{22}$ at the 1965 Conference for Comparative Law in Kiel relied heavily on the American solution, which was based on (strict) extra-contractual liability. Three years later, in 1968, the German Supreme Court followed this approach by making available a delictual claim and approximating it to strict liability by shifting the burden of proof for negligent misconduct to the producer. The concept of Verkehrspflichten, which comes close to the duty of care, was also strongly influenced by Anglo-American legal thinking. ${ }^{93}$

\section{(d) Law of Restitution}

Again, it was von Caemmerer who revolutionized the law of restitution. $\mathrm{He}$ declared all attempts to find a comprehensive formula to cover unjust enrichment claims to be unfruitful. Instead, he stressed the fundamental difference between the Leistungskondiktion, or claim for the restitution of a benefit conferred by the plaintiff's own act, and the Eingriffskondiktion, a claim based on an interference with the rights of another person..$^{44}$ Von Caemmerer's former assistant, Detlef König, subsequently elaborated the comparative foundations for a new system of restitutionary claims ${ }^{95}$ that was to culminate in the monumental two volume study

91 Ernst von Caemmerer, 'Wandlungen des Deliktsrechts', in idem, Gesammelte Schriften (n 88), 452.

92 Werner Lorenz; Die Haftung des Warenherstellers (1966).

93. See the impressive monograph by Christian von Bar; Verkehrspflichten: Richterliche Gefahrsteuerungsgebote im deutschen Deliktsrecht (1980). Another important comparative work is Hans Stoll, Das Handeln auf eigene Gefahr (1961).

94 Ernst von Caemmerer, 'Bereicherung und unerlaubte Handlung' in idem, Gesammelte Schriften (n 88), 209.

95 Published only posthumously; Detlef König, Ungerechtfertigte Bereicherung: Tatbestände und Ordnungsprobleme in rechtsvergleichender Sicht (1985). 
on restitution by Peter Schlechtriem (another of von Caemmerer's pupils) in 2000-01.96 These ideas were adopted by several Swiss authors in the $1980 .^{97}$

\section{(e) Family Law and the Law of Succession}

Comparative studies in family law first dealt with the problems concerning equal rights for women, which had to be addressed as a result of the equality clause in the Basic Law (Grundgesetz) of 1949. Soon thereafter, comprehensive studies on family law emanated from the Hamburg Max Planck Institute, such as Dölle's two volumes on family law in 1964 or Paul Heinrich Neuhaus's study on marriage and the law of children. ${ }^{98}$ One of the great, early comparatists in family law was Wolfram Müller-Freienfels, who not only incorporated Anglo-American law into his research, but also Japanese law. He even took account of revolutionary family law legislation, such as Chinese or Russian law. ${ }^{99}$

Comparative research depends upon the availability of foreign legal sources. Two comprehensive projects have to be mentioned here, one by Ferid and Firsching on the international law of succession, the other by Bergmann and Ferid on the international law of marriage and children. Both are compilations of the translated and annotated statutory provisions in the respective fields from all over the world. 100

\section{(f) Conflict of Laws}

One would expect the field of conflict of laws to be especially open to comparative legal research, in view of its international character. ${ }^{101}$ However, in post-war Germany the approach to conflict of laws was still firmly based on Savigny's conceptual ideas. Substantive policy considerations, except for the ordre public reservation, were not taken into account. This restrictive approach was only rarely challenged among German legal scholars. It was not until 1971 that the German Constitutional Supreme Court, in what was to become one of its most important leading cases, decided that the provisions of German private international law, as well as the applicable foreign law, have to be measured in conformity with the value

96 Peter Schlechtriem, Restitution und Bereicherungsausgleich in Europa (2 vols, 2000-01).

97 See the references provided in Schwenzer ( $\mathrm{n} 80$ ), 74.

98 Hans Dölle, Familienrecht (2 vols, 1964-65); Paul Heinrich Neuhaus, Ehe und Kindschaft in rechtsvergleichender Sicht (1979).

99 Wolfram Müller-Freienfels, Ehe und Recht (1962); idem, 'Zur revolutionären Familiengesetzgebung, insbesondere zum Ehegesetz der Volksrepublik China', in Ius privatum gentium: Festschrift für Max Rheinstein zum 70. Geburtstag (1969), 843; idem, Familienrecht im In- und Ausland, Aufsätze (3 vols, 1978-94).

100 Murad Ferid and Karl Firsching (eds), Internationales Erbrecht: Quellensammlung mit systematischen Darstellungen des materiellen Erbrechts sowie des Kollisionsrechts der wichtigsten Staaten (1955 ff); Murad Ferid and Alexander Bergmann, Internationales Ehe- und Kindschaftsrecht: mit Staatsangehörigkeitsrecht (1952 ff).

101 For what follows see Martinek (n 68), 581. 
system laid down in the Grundgesetz. ${ }^{102}$ Although the creative US-American 'conflicts revolution', with its governmental interest analysis (Currie), lex-foriapproach (Ehrenzweig), or better-law approach (Cavers, Leflar, Juenger), did not go totally unnoticed, the conservative approach in Germany prevailed. The so-called political school of conflicts analysis, which mostly relied on modern thinking from the United States and is linked to the names of Rudolf Wiethölter and Christian Joerges, has been isolated by the prevailing traditionalists and their representatives, such as Eric Jayme, Gerhard Kegel, Paul Heinrich Neuhaus, Egon Lorenz, or Klaus Schurig.

\section{Comparative Law in Legislation and Courts}

'Legislative comparative law' has been described as one of the oldest, as well as most fundamental, purposes of comparative legal scholarship. ${ }^{103}$ However, Rabel's uneasiness with legislative comparative law, which he tended to regard as methodologically suspicious, has not lost its relevance today. Consequently, although foreign laws are usually considered in the preparation of major law reform projects, more often than not a truly comparative approach is lacking, and only a very restricted selection of legal systems is taken into account. Political reasons, such as the systematic ignorance of the law of the socialist countries, were part of the cause, but there were also more practical problems, such as those arising from a failure to understand foreign languages. Thus, in 1981, Ferid accused the German legislature of not having taken account of French law in the family law reform projects of 1969 and 1976, and of ignoring French and Italian solutions when drafting the Act on Standard Terms of Business in 1976. 104

But even in Switzerland, with its linguistic diversity, the comparative consideration of foreign legal systems outside the 'Germanic legal family' cannot be taken for granted. Very often, German solutions are simply adopted into Swiss law. Thus, although the preparatory works for the Swiss family law reform in 1995 demonstrated considerable interest in the broader European legal development, ${ }^{105}$ some of the articles eventually adopted are a mere reproduction of German law. Thus, for example, Art 125 III ZGB on the exclusion of maintenance claims between divorced spouses has its direct counterpart in $\$ 1579$ BGB. Even more significantly, the elaboration of a Swiss Federal Code of Civil Procedure, which is under way at the moment, is based upon a comparison of the statutory provisions

102 BVerfGE 31, 58 = [1971] Neue Juristiche Wochenschrift 1509.

103 See Helmut Coing, Europäische Privatrecht, vol II: 19. Jahrhundert (1989), 56 et seq.

104 Murad Ferid, 'Die derzeitige Lage von Rechtsvergleichung und IPR in der Bundesrepublik Deutschland', (1981) 22 Zeitschrift für Rechtsvergleichung 86, $87 \mathrm{ff}$.

105 Bundesblatt der Schweizerischen Eidgenossenschaft 1996 I 1. 
of the twenty-six Swiss cantons, whereas foreign laws are almost completely disregarded.

The use of comparative law by courts was one of the subjects of the XIVth International Congress of Comparative Law in Athens. Using as a starting-point Zweigert's famous assertion in 1949, that comparative law was to be regarded as a universal method of interpretation, most contributors to the Congress had to acknowledge that comparative law is usually no more than an additional argument for supporting a decision that has already been arrived at on other grounds. It has been suggested that one should classify court decisions which rely upon comparative law according to the motivation behind the courts' use of foreign law (which can be necessary or voluntary), and that one should additionally distinguish its use in cases involving rules with an international element from those which are of purely domestic character. ${ }^{106}$ Rules with an international element seem particularly suitable for a comparative approach to interpretation. This proposition has, on a general level, even received support from the German Federal Supreme Court. It has held that rules of internationally uniform law cannot be interpreted as one would any other rule of national law, but rather must be approached with the aim of guaranteeing a uniform interpretation in all contracting states. ${ }^{107}$ However, the practical consequences of this assertion are less visible. Very often, provisions of international origin are implemented into German law as if they were genuinely indigenous German law, passed by the German legislature. The result is that those who have to apply the law, especially the courts, tend to forget that a provision is part of an international convention, and so do not pay attention to its comparative origins. As a result, these 'international' provisions are interpreted from a merely national point of view which, in turn, leads to a 'renationalization' of international law. This is especially true for the implementation of many Hague Conventions in the field of conflict of laws.

It has already been noted above that German law dominates in Swiss legal scholarship. The consequences can be observed by analysing not only Swiss legislation but also the decisions of the Swiss Federal Supreme Court. A comprehensive study has revealed that--even if, compared to other Supreme Courts in Europe, the Federal Supreme Court displays a relatively friendly attitude towards foreign legal systems-9o per cent of all references to foreign law were to German law. ${ }^{108}$ Furthermore, in most cases comparative arguments do not play a decisive role in the process of decision-making.

\footnotetext{
106 Ulrich Drobnig, 'General Report', in Ulrich Drobnig and Sief van Erp (eds), The Use of Comparative Law by Courts (1999), 3, 6.

107 See Ulrich Drobnig, 'National Report Germany', in Drobnig and van Erp (n 106), 127, 132.

108 Alexandra Gerber, 'Der Einfluss des ausländischen Rechts in der Rechtsprechung des Bundesgerichts', in Perméabilité des ordres juridiques: Rapports présentés à l'occasion du colloqueanniversaire de l'Institut suisse de droit comparé (1992), 141; 143.
} 


\section{Legal Harmonization and New Approaches to Comparative LaW}

The end of the cold war in 1989 may be seen as the beginning of a new chapter in the development of comparative law.

\section{Development of the German Bürgerliches Gesetzbuch}

There were a number of legal scholars who hoped that the reunification of the two German states in 1990 might trigger an increased interest in comparison. Especially in the field of family law, it was expected that the solutions adopted in the German Democratic Republic's Family Code of 1965 would be taken into account. Though partly influenced by socialist legal thinking, many of its provisions reflected a modern approach that had also manifested itself in a number of other Western legal systems, for example in the law concerning children in France or the Scandinavian countries. However, these hopes were dashed by the Unification Treaty of 1990, which introduced the provisions of the BGB as it was still in force in the German Federal Republic, with only a few reservations. ${ }^{109}$ Thus, the distinction between marital and non-marital children, which had been abolished in 1965 in the German Democratic Republic, was reintroduced into the so-called new German Länder. It was not until 1998 that the entire law relating to children was comprehensively revised, based mainly upon the deliberations of the Deutscher Juristentag in 1992, with its thorough comparative report. 110

In the late 1970s, the German government had started the process of a fundamental revision of the German law of obligations. As a first step, leading German scholars were asked to prepare comparative reports which were to serve as a basis for the reform. ${ }^{111}$ In 1984, a Reform Commission was established to prepare a draft. As a result of the influence of two eminent comparatists who were members of the commission, Hein Kötz and Peter Schlechtriem, the final report of $1992^{112}$ represented modern comparative legal thinking. In the fields of breach of contract and

109 Art 230 I EGBGB and Art 235\$ I II EGBGB. See Dieter Schwab (ed), Familienrecht und deutsche Einigung: Dokumente und Erläuterungen (1991).

110 Ingeborg Schwenzer, Empfiehlt es sich, das Kindschaftsrecht neu zu regeln? Gutachten A zum 59. Deutschen Juristentag (1992).

111 Bundesministerium der Justiz (ed), Gutachten und Vorschläge zur Überarbeitung des Schuldrechts (3 vols, 1981-83). Later, a further comparative report concerning the development of the law of sales was given on behalf of the Hamburg Max Planck Institute: Jürgen Basedow, Die Reform des deutschen Kaufrechts (1988).

112 Bundesministerium der Justiz (ed), Abschlussbericht der Kommission zur Überarbeitung des Schuldrechts (1992). 
the law of sales, the draft mostly reflected the solutions found in the CISG. The draft was favourably received by the sixtieth Deutscher Juristentag in 1994. However, apart from that, there was no broadly based discussion of the draft, which appeared to be consigned, increasingly, to oblivion. It was only the enactment of the EC Consumer Sales Directive and the need for its implementation by 1 January 2002 that revitalized the idea of a fundamental revision of the law of obligations. However, the so-called Discussion Draft published by the German government in September 2000 was heavily criticized by German traditionalists, who were still inspired by nineteenth-century pandectist legal thinking. The Ministry of Justice, therefore, charged another commission, whose members were not comparatists, with the task of revising the Discussion Draft. This led to modifications diluting the international and comparative approach, and reintroducing peculiarly pandectist thinking into the final draft which came into force in 2002.

\section{The Interpretation of Uniform Law}

The tendency to interpret internationally uniform legal instruments against a national legal background has already been mentioned. This was also true, initially, for one of the most successful uniform laws so far: the international sales convention (CISG). Thus, for example, German courts at first interpreted the CISG provisions requiring the buyer to give notice in case of a delivery of nonconforming goods in precisely the same way as the corresponding provisions in the German Commercial Code. The courts thus simply ignored the fact that other national sales laws do not recognize a notice requirement at all, and that courts from these countries would never adopt an approach as rigorous as that favoured by the German courts, who apply time limits of less than one week. Modern commentaries on the CISG, on the contrary, follow a truly comparative approach. They not only consider the differences in national sales laws that influenced the drafting of the convention, but also closely observe and register the application and interpretation of the convention by foreign courts and scholars all over the world. ${ }^{113}$ Slowly, this approach is also influencing the judiciary.

\section{Europeanization}

Over the past fifteen years, EC Directives have had an ever-growing impact on core areas of private law. These Directives have to be implemented by the various

113 See the leading commentary by Peter Schlechtriem and Ingeborg Schwenzer, Commentary on the UN Convention of the International Sale of Goods (CISG) (2nd edn, 2005). This approach is supported by the operation of a database that gathers all relevant court decisions; see <www.cisgonline.ch>. 
national legislatures in the EU member states. However, it is commonly understood that national judges should take account of the judicial and academic interpretation of the harmonized provisions in the other member states, although this ideal is hard to realize in the real world of national courts. Still, uniform interpretation is facilitated by the existence of the European Court of Justice and the European Court of First Instance.

Switzerland, despite not being a member of the EU, has enacted several statutes which automatically follow the relevant EC Directives, and thus also pursue the aim of European legal harmonization. In many cases, however, the European origin of these statutes is not obvious. This is one of the reasons why no consideration is usually given to the judicial development of these matters in the EU member states or by the European Court of Justice.

In spite of the growing number of Community Directives, they are nothing more than 'islands' in 'the great ocean of international private law', as the European Parliament has described the situation.:"14 Outside those 'safe harbours', economic players 'risk running aground on shallows consisting of either unresolved conflicts of individual private law regulations or the absence of coordination between European law and international private law'. What is still lacking to this very day is a general contract law, or general rules for the law of obligations. The call for unification, or at least harmonization, in this field is constantly growing. International unification has always been one of the aims of comparative law, and so it is not surprising that the 1990s saw scholars in this field eagerly taking up the challenge of Europeanization of private law. Two different movements may be distinguished, both of them emanating from Germany:115 the one may be called the classical comparative approach, the other the ius commune approach.

\section{(a) The Classical Comparative Approach}

During the last decade, comprehensive research has revealed a 'common European core' of national solutions in many areas within the law of obligations. It is characteristic of these studies that they no longer consist of country reports; instead, they focus on the functional treatment of practical issues. In 1996, Hein Kötz published the first volume of Europäisches Vertragsrecht, ${ }^{116}$ which deals with the formation, validity, and content of contracts, as well as the participation of third parties in contractual relationships (agency, contracts for the benefit of third

\footnotetext{
114 European Parliament, Report on the Approximation of the Civil and Commercial Law of the Member States of 6 Nov 2001 (A5-0384/2001).

115 For details, see Chapter 16 in this Handbook.

116 Hein Kötz, Europäisches Vertragsrecht (1996) (English translation under the title European Contract Law by Tony Weir, 1997).
} 
parties, and assignment). In his two-volume work, Gemeineuropäisches Deliktsrecht, ${ }^{117}$ Christian von Bar, in 1996 and 1999, set out the common core of European tort law. Similarly, in his work entitled Restitution und Bereicherungsausgleich in Europa, ${ }^{118}$. Peter Schlechtriem elaborated the comparative basis for projects of harmonization and unification in the field of restitution and unjustified enrichment.

\section{(b) The Ius Commune Approach}

In 1947, in the aftermath of World War II, Heinrich Mitteis called for legal history to focus not on the specificities of national legal development, but on the ius commune in order to devise a 'pan-European legal history on a comparative basis'. 119 The idea of a European ius commune has gained new ground as a result of important research which stresses the similarities between the common law and civil law, closely linked to the name of Reinhard Zimmermann, who is one of the current directors of the Max Planck Institute in Hamburg. In 1990, he initiated the discussion with his work on the Law of Obligations, which adopts both a historical and a comparative approach. ${ }^{120}$ The proximity of legal history and comparative law has long been accepted by comparative scholars. It may be recalled in this context that Ernst Rabel himself was originally a legal historian who never neglected to trace the historical origins of legal rules. Leading comparatists have often referred to legal history as 'vertical comparative law'. Among legal historians, however, this approach is strongly challenged by scholars who argue that legal history constitutes an integral part of historical scholarship. For them, it cannot be the aim of legal history to scrutinize the development of legal systems in order to gain a better understanding of the modern law. Legal history, in other words, should not serve as an instrument of contemporary law making.

Whereas Zimmermann and others take the view that a common tradition can be the starting-point for harmonizing and unifying European law today, others doubt that an unbroken continuity exists between the ius commune and modern law. ${ }^{121}$ They suspect that the ideas of nineteenth-century pandectist scholarship are being re-animated without, however, being able to contribute to the solution of modern problems. All too often, the reference to Roman roots only serves to reinforce national legal preoccupations. Thus, for example, the study group on a European Civil Code discussed at length the unfruitful question whether the transfer of

\footnotetext{
117 Christian von Bar, Gemeineuropäisches Deliktsrecht (2 vols, 1996 and 1999) (English translation under the title The Common European Law of Torts, 1999 and 2001).

118 Peter Schlechtriem, Restitution und Bereicherungsausgleich in Europa (2 vols, 2000 and 2001).

119 Heinrich Mitteis, Vom Lebenswert der Rechtsgeschichte (1947), 54.

120 Reinhard Zimmermann, The Law of Obligations: Roman Foundations of the Civilian Tradition (1990; paperback edn, 1996).

121 Regina Ogorek, 'Rechtsgeschichte in der Bundesrepublik (1945-1990)', in Simon (n 68), 12, 57.
} 
property should be causally linked to the underlying contract, or whether the principle of abstraction should be adopted. ${ }^{122}$

\section{(c) Practical Endeavours}

Since the 1980s, several projects have been launched, with strong participation of German scholars, to elaborate European principles that might conceivably serve, one day, as a basis for a European Code. The working method has been influenced by the American Restatements. A Commission on European Contract Law has drafted Principles of European Contract Law (PECL) and presented them to the public in three stages. ${ }^{123}$ Whereas the Commission on European Contract Law concentrated on general contract law, the Study Group on a European Civil Code, founded in 1998, expanded their agenda to special contracts, property law, and non-contractual obligations. In the field of family law, a Commission on European Family Law was established in 2001 and published the first part of its Principles of European Family Law in 2004. ${ }^{124}$ But there are also other groups which have set themselves the task of formulating uniform rules. Thus, the so-called Pavia Group published a preliminary draft of a European Contract Code in 2001, ${ }^{125}$ which, however, is heavily based on continental and pandectist legal thinking and may not, therefore, really be attributed to modern comparative legal research. Finally, a European Group on Tort Law, based in Vienna and coordinated by the Austrian scholar Helmut Koziol, published a set of Principles of European Tort Law in $2005^{126}$

\section{Criticism}

The postmodern criticism of traditional comparative law that has been formulated, especially by American legal scholars, has gone virtually unnoticed among German comparatists. ${ }^{127}$ One of the major points of criticism is that comparative law scholarship still focuses on a limited number of national legal orders. This is

122 Peter Schlechtriem, 'Europäisierung des Privatrechts-vom Beruf unserer Zeit für ein europäisches Privatrecht', 2004 Juridica international 24, 31.

123 Ole Lando and Hugh Beale (eds), Principles of European Contract Law, Part I (1995); Ole Lando and Hugh Beale (eds), Principles of European Contract Law, Parts I and II (2000); Ole Lando, Eric Clive, André Prum, and Reinhard Zimmermann (eds), Principles of European Contract Law, Part III (2003).

124 Katharina Boele-Woelki, Frédérique Ferrand, Cristina González Beilfuss, Maarit JänteräJareborg, Nigel Lowe, Dieter Martiny, and Walter Pintens, Principles of European Family Law Regarding Divorce and Maintenance between Former Spouses (2004).

125 Giuseppe Gandolfi (ed), Code européen des contrats (2001).

126 European Group on Tort Law (ed), Principles of European Tort Law: Text and Commentary (2005).

127 See Peters and Schwenke (n 1 ). 
particularly valid in view of the fact that German comparative lawyers are strongly involved in the above-mentioned projects concerning the harmonization of private law on a European level. Prominent authors have even claimed that questions of European harmonization should be clearly distinguished from comparative law in general. ${ }^{128}$ Whether or not one subscribes to this view, it is obvious that a restriction of the comparative law agenda to European private law carries with it the inherent danger of isolation. Further legal development in Europe, from a global point of view, should not lead merely to the implementation of specifically European solutions, that is, of a kind of nationalism on a larger scale. Future comparison and harmonization projects should take account, apart, of course, from the United States, of Australia and New Zealand, two vigorous common law jurisdictions which have many interesting and innovative solutions to offer. Traditional laws may also harbour unknown treasures which provide answers to current problems.

\section{Conclusion}

Professional historians deeply distrust lawyers who write about the history of legal scholarship, for they often regard them as over-optimistic and prone to telling uncritical stories of success. Professional historians prefer to see gaps and ruptures.

The history of comparative law during the last century can indeed be seen as a success story: institutes have been founded which are flourishing and which have produced much impressive work. Most law makers today no longer adopt new rules without referring to comprehensive comparative research. In addition, courts of law increasingly take comparative aspects into consideration. Although the Nazi period can be regarded as a deep rupture, post-war comparative legal scholarship built upon the successes of the glorious past of the Weimar Republic. The age of globalization shows its impacts on legal scholarship too: all attempts at harmonization are based on comprehensive research, and scholars in comparative law are highly esteemed experts, not only in their respective areas of research, but also in the field of law in general. English has effectively become the new lingua franca and also has a considerable impact on legal research, which is becoming more and more international. Students and young scholars often go for postgraduate studies to Anglo-American law schools, ${ }^{129}$ which also contributes to a gradual convergence

128 Christian von Bar, 'Comparative Law of Obligations: Methodology and Epistemology', in Mark van Hoecke (ed), Epistemology and Methodology of Comparative Law (2004), 123, 131.

129 See Wolfgang Wiegand, 'The Reception of American Law in Europe', (1991) 39 AJCL 229. 
of legal systems. This type of narrative is very common in articles which focus on the history of comparative law, and it also underlies the present chapter, at least to some extent.

In contrast, contributions which refer to the contemporary state of comparative law have often referred to, and still refer to, the relative insignificance of this branch of legal scholarship. The authors of such contributions deplore the ignorance of the rest of the legal community of other legal systems, the bad institutionalization of comparative law, and its shadowy existence in the general curriculum at universities. They criticize bad decisions of national courts of law which ignore foreign solutions or, on the contrary, adopt them blindly without taking into consideration their functional context. Traces of those complaints can also be found in the present chapter. We need only recall the recent revision of the law of obligations in the Bürgerliches Gesetzbuch in Germany in 2002.

Thus, the question arises as to how these divergent views should be evaluated and how comparative law is going to develop in the future. Comparative law undoubtedly has achieved much, and it has enhanced legal knowledge in an impressive way. But it cannot be denied that it has always been confined to a minority of scholars, who may be regarded as an elite. It has never gained broad recognition; either as a special branch of legal scholarship; or as an integrated part of legal scholarship in general. It has been said that there has never been a meaningful communication between comparative law and the traditional core of German legal doctrine. It has been argued that Ernst Rabel himself contributed to this estrangement by insisting on high professional standards, thus raising fears among those who might otherwise have been willing to venture beyond the purely national sources of law that they might be accused of dilettantism..$^{130}$

On the other hand, one would love to speculate about what would have happened if the 'dark age' of German legal history had not taken place and if, instead, Rabel and his staff could have continued their work without disruption and thus possibly have achieved their ambitious goal, which was to remodel German law on a comparative basis. ${ }^{131}$

In the future, the importance of comparative law will largely depend on whether students are trained in this field from the very beginning of their studies. Up until now, this has not been the case in Germany, Switzerland, or Austria. Comparative law (if it exists at all) is still only one optional course among many others, and it even runs the danger of being further reduced in view of the rapid rise of European Community law. The tendency mentioned above of more and more young people studying abroad does not, per se, replace the need for a basic comparative

\footnotetext{
130 Jürgen Basedow, 'Der Standort des Max Planck-Instituts-Zwischen Praxis, Rechtspolitik und Privatrechtswissenschaft', in Jürgen Basedow and Ulrich Drobnig (eds), Aufbruch nach Europa: 75 Jahre Max-Planck-Institut für Privatrecht (2001), 3, 12.

131 Rabel (n 19), 19.
} 
education. Much too often, those exchanges only add knowledge of a foreign legal system to that of the respective person's own legal system, without really furthering a comparative understanding. This can result in an uncritical reception of foreign legal notions and practices, as has indeed happened in many fields of the legal profession where American customs and rules have simply been blindly adopted.

To summarize, then, the history of comparative law bears testimony to remarkable successes as well as constant obstacles which, to this very day, still prove hard to overcome.

\section{B IB LIO G RA P H:X}

Hans Dölle, 'Der Beitrag der Rechtsvergleichung zum deutschen. Recht', in Ernst von Caemmerer, Ernst Friesenhahn, and Richard Lange, Hundert Jahre deutschen Rechtslebens: Festschrift zum hundertjährigen Bestehen des Deutschen Juristentages 1860-1960 (vol II, 1960), $19 \mathrm{ff}$

Léontin-Jean Constantinesco, Rechtsvergleichung (3 vols, 1971-83)

Marcus Lutter, Ernst C. Stiefel, and Michael H. Hoeflich (eds), Der Einfluss deutscher Emigranten auf die Rechtsentwicklung in den USA und in Deutschland (1991)

Michael Martinek, 'Wissenschaftsgeschichte der Rechtsvergleichung und des internationalen Privatrechts in der BRD', in Dieter Simon (ed), Rechtswissenschaft in der Bonner Republik, Studien zur Wissenschaftsgeschichte der Jurisprudenz (1994), 529, 552

Elmar Wadle, Einhundert Jahre rechtsvergleichende Gesellschaften in Deutschland (1994)

Reinhard Zimmermann, The Law of Obligations: Roman Foundations of the Civilian Tradition (1990; paperback edn, 1996)

Ingeborg Schwenzer, 'Rezeption deutschen Rechtsdenkens im schweizerischen Obligationenrecht', in eadem (ed), Schuldrecht, Rechtsvergleichung und Rechtsvereinheitlichung an der Schwelle zum 21. Jahrhundert (1998), 59 ff

Konrad Zweigert and Hein Kötz, Einführung in die Rechtsvergleichung (3rd edn, 1996); English translation under the title An Introduction to Comparative Law by Tony Weir (3rd edn, 1998)

Rolf Ulrich Kunze, Ernst Rabel und das Kaiser-Wilhelm-Institut für ausländisches und internationales Privatrecht 1926-1945 (2004) 

This offprint is taken from:

Reimann and Zimmermann: The Oxford Handbook of Comparative Law

978-0-19-929606-4 November 2006 $£ 120.00 \quad$ Hardback $1456 \mathrm{pp}$

For more information on this offprint or the editorial process, please contact:

Gwen Booth

Development Editor, Academic Law

Oxford University Press

Great Clarendon Street

Oxford OX2 6DP

Email: gwen.booth@oup.com

To order your copy:

By telephone: $+44(0) 1536741017$

By fax: $+44(0) 1536454518$

By email:

By Post:

bookorders.uk@oup.com

OUP

Saxon Way West

Corby, Northamptonshire

NN18 9ES

If you would like more information on this or any other OUP title, or would like to receive the latest OUP law catalogue, please contact:

\section{Sarah Ultsch}

Head of Marketing - Law Department

Oxford University Press

Great Clarendon Street

Oxford $O X 26 D P$

Email: law.uk@oup.com

Visit our website at http://www.oup.com/uk/law 